\title{
Strategi Persuasif dalam Sale Promotion dengan Outdoor Ad Media: Studi Kasus Bahasa Persuasif Pedagang Kaki Lima Di Denpasar Selatan
}

\author{
Sri Widiastutik ${ }^{1 *}$, I Putu Bagus Arya Githa Wibawa ${ }^{2}$, Indah Amalia Shofiana ${ }^{3}$ \\ ${ }^{1,2,3}$ STMIK STIKOM, Indoesia
}

*Email: sriwidiastutik@stiki-indonesia.ac.id

\begin{abstract}
Creative and quality promotional strategies require interaction and communication in attractive language, so that the marketed product can be easily understood and accepted by community. Language has an important role in supporting marketing, especially in conveying information related to business products carried out through various media, such as outdoor advertising media which is widely used by small business actors. This study aims to describe the use of persuasive expressions in outdoor ads media such as hanging/roll banners by street traders (PKL) and describe the meaning of messages contained. This study used a field research of qualitative descriptive method by analysis the form of persuasive words/sentences on outdoor advertising media of street traders in the southern area of Denpasar as the research data. The technique of providing data was carried out by surveying the location of street traders in side of the road and storefronts, interviews and distribution of questionnaires. Furthermore, data collection in this study used the listening method with note-taking and documentation techniques. The data analysis method was used an extra lingual equivalent approach to classify the form of using persuasive language and the impact of the message contained in the hanging banner/standing banner. The results of this study was pointed out that $\geq 80 \%$ persuasive language promotion strategy in banner media has become the main strategy for PKL, efficiently persuasive language messages can quickly invite public appeal so that it is very likely to increase the purchasing power of potential consumers directly.
\end{abstract}

Keywords : persuasive language, media, outdoor advertising, street traders

\begin{abstract}
Abstrak
Strategi promosi yang kreatif dan berkualitas perlu dilakukan interaksi dan komunikasi dengan bahasa yang menarik, supaya produk yang dipasarkan dapat mudah dipahami dan diterima oleh masyarakat luas. Bahasa mempunyai peran penting dalam mendukung pemasaran, terutama dalam menyampaikan informasi terkait produk usaha yang dilakukan melalui berbagai media, seperti media outdoor advertising yang banyak digunakan oleh para pelaku usaha kecil. Penelitian ini bertujuan untuk mendeskripsikan gaya bahasa persuasif yang tertulis pada media outdoor ad (spanduk/banner) oleh Pedagang Kaki Lima (PKL) dan mendeskripsikan makna pesan yang terkandung pada bahasa persuasif dalam media tersebut. Penelitian ini menggunakan metode field research yang bersifat deskriptif kualitatif. Teknik penyediaan data dilakukan melalui survei lokasi PKL di pinggir jalan dan emperan toko, wawancara dan pendistribusian kuesioner di wilayah Denpasar Selatan. Pengumpulan data dalam penelitian ini menggunakan metode simak dengan teknik catat dan dokumentasi. Metode analisis data yang digunakan, yaitu pendekatan padan ekstralingual untuk mengklasifikasikan wujud penggunaan bahasa persuasif dan dampak isi pesan yang terkandung dalam spanduk/banner. Hasil penelitian ini menunjukkah bahwa $\geq 80 \%$ strategi promosi bahasa persuasif pada media banner telah menjadi strategi utama bagi PKL, secara efisien pesan bahasa persuasif dapat dengan cepat mengundang daya tarik masyarakat sehingga sangat berpeluang meningkatkan daya beli calon konsumen secara langsung.
\end{abstract}

Kata kunci : bahasa persuasif, media, outdoor advertising, Pedagang Kaki Lima 


\section{Pendahuluan}

\subsection{Latar Belakang}

Pada jaman modern ini eksistensi media promosi di dunia usaha merupakan hal terpenting digunakan oleh para pelaku usaha. Para pelaku usaha kecil maupun besar menggunakan beragam media iklan mulai dari media dengan model indoor hingga outdoor. Saat ini media outdoor advertising cenderung abadi digunakan para pelaku usaha, seperti billboard, spanduk, maupun banner saat melintas di pinggir jalan sepanjang ada kegiatan usaha. Dengan perkembangan teknologi informasi, beragam media promosi dengan model outdoor advertising tetap unggul seiring dengan lahirnya media-media digital, namun tidak menutup jalan bagi media outdoor berkreasi dalam menyebarluaskan infomasi terkini dan relevan kepada masyarakat. Bahkan, media outdoor selalu dijadikan sebagai rujukan utama bagi para pengusaha mikro dan menengah saat hendak mempromosikan produk penjualan. Dengan dukungan teknologi, media outdoor pun memanfaatkan teknologi dalam proses pencetakan, desain dan proses penyebaran informasi.

Peran media outdoor dalam mempromosikan penjualan bagi pelaku usaha adalah hal penting untuk dilakukan terutama saat memulai sebuah usaha. Pesan iklan atau konten promosi yang akan disampaikan dalam media outdoor tersebut bertujuan untuk menawarkan produk dan jasa dengan menyesuaikan karakter kebutuhan masing-masing usaha supaya dapat dengan mudah dikenali masyarakat. Secara sederhana pesan yang biasa dikenal dengan sebutan "iklan" ini harus disampaikan sesuai dengan tujuan pelaku usaha. Menurut kamus Bahasa Indonesia (2008), iklan berarti informasi tentang pesanan untuk mendorong, membujuk khalayak ramai agar tertarik pada barang dan jasa yang ditawarkan, atau pemberitahuan kepada khalayak mengenai barang atau jasa yang dijual dengan dipasang di tempat umum. Dalam pengertian yang lebih luas, iklan merupakan pesan komunikasi pemasaran atau komunikasi publik tentang sesuatu produk yang disampaikan melalui sesuatu media, dan ditujukan kepada masyarakat (Asmaunizar, dkk, 2020).

Menurut beberapa pakar "promosi” berasal dari kata promote dalam bahasa Inggris yang diartikan sebagai mengembangkan atau meningkatkan. Pengertian tersebut jika dihubungkan dengan bidang penjualan berarti sebagai alat untuk meningkatkan omzet penjualan. Promosi adalah arus informasi atau persuasi satu arah yang dibuat untuk mengarahkan seseorang atau organisasi kepada tindakan yang menciptakan pertukaran dalam pemasaran (Swastha, 2007: h.222). Menurut ahli pemasaran (Boyd, 2000) promosi diartikan sebagai upaya membujuk orang untuk menerima produk, konsep dan gagasan. Promosi merupakan kegiatan-kegiatan yang ditujukan untuk mempengaruhi konsumen agar mereka dapat menjadi kenal akan produk yang ditawarkan oleh perusahaan kepada mereka dan mereka menjadi senang lalu membeli produk tersebut (Gitosudarmo, 2000).

Tujuan utama promosi adalah produsen atau distributor akan mendapatkan kenaikan angka penjualan dan meningkatkan profit atau keuntungan (Tjiptono, 2008: h.221). Sedangkan jenis promosi dalam penelitian ini merupakan jenis promosi melalui media tradisional, yaknimelalui media cetak seperti koran, majalah, tabloid, dan sejenisnya, dan media elektronik seperti radio dan televisi, serta media di luar ruangan seperti iklan banner, spanduk atau papan reklame atau papan billboard.

Keberhasilan promosi ditentukan oleh beberapa faktor, salah satunya adalah bahasa. Jika kita perhatikan, promosi maupun iklan yang bertebaran di berbagai media terlihat dengan jelas dirancang dengan menggunakan kata-kata, frasa, dan kalimat dengan tujuan untuk menyampaikan informasi atau mempersuasi khalayak untuk merubah sikap atau melakukan tindakan tertentu. Penggunaan gaya bahasa persuasif tersebut haruslah mampu dibuat semenarik mungkin, berupa kata-kata yang nyeleneh, warna dan gambar-gambar yang menarik perhatian, dan dapat memainkan emosi khalayak seperti menimbulkan rasa penasaran, harapan, keinginan, kesadaran, rasa bersalah, sehingga mampu mengubah perilaku konsumen dengan membeli produk dagangannya. 


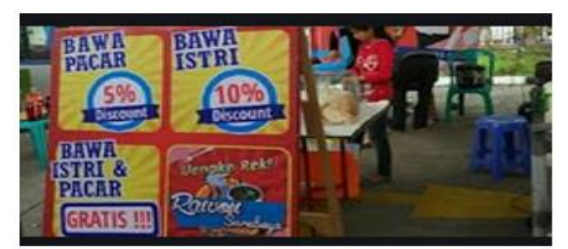

Gambar 1. Promo diskon PKL

(Sumber: Peneliti, 2020)

Strategi promosi para PKL (Pedagang Kaki Lima) dengan gaya persuasif seperti promo diskon menggunakan kata-kata atau frasa yang cenderung "nyeleneh" demi menggaet banyak pembeli. Secara normal, semua orang sangat suka dengan promo, apalagi promo yang "nyeleneh", seperti bahasa persuasif dengan trik menuliskan potongan atau diskon harga menu nasi campur. Bahasa persuasif pada standing banner ini bertujuan untuk menarik minat pembeli dengan adanya diskon dari harga normal. "Bawa Istri 5\%" (Jika konsumen datang membeli suami bersama istri, maka akan mendapatkan potongan harga sebesar 5\%); "Bawa Pacar Diskon 10\%" (Jika konsumen datang membeli bersama pacar, maka akan mendapatkan potongan harga sebesar 10\%). Bahkan, ditemukan tulisan antimainstream dalam spanduk yang membuat konsumen merasa geregetan melihatnya, sehingga muncul rasa penasaran, seperti tampak pada spanduk/banner PKL berikut.
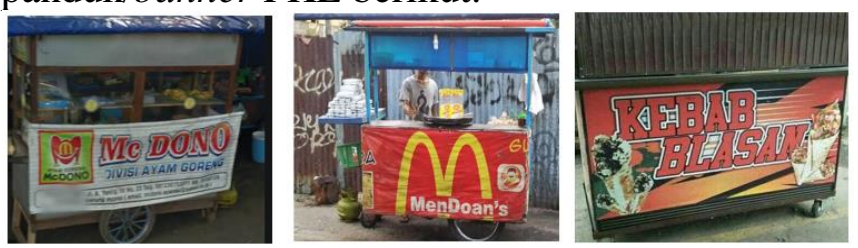

Gambar 2. Gaya Bahasa promosi: Mc Dono, M-Medoan's, Kebab-Blasan (Sumber: Peneliti, 2020)

Simbol huruf "M" - Mendoan, M adalah kependekan dari kata Mendoan adalah istilah dari Bahasa Jawa yang artinya gorengan dari bahan tempe dibumbu bacem. "Mc DONO" yang menunjukkan pedagang bernama Dono, walaupun orang tahu bahwa " $M c$ " sering kita jumpai hanya digunakan pada brand makanan " $M c$ Donald". Namun pedagang menggantinya dengan "McDONO sebagai simbol dari ciri khas produk makanan ayam goreng yang dijualnya.

"KEBAB BLASAN" berasal dari kata "kebab" dengan tujuan pedagang menjual produk makanan kebab, namun diplesetkan supaya tampak unik menjadi "kebablasan". Kebab adalah penganan cepat saji terdiri atas daging sapi yang dipanggang seperti satai kemudian diiris-iris ditambah dengan sayuran segar dan mayones, lalu dibalut dengan kulit tortila. Sedangkan "kebablasan" berasal dari Bahasa daerah, jawa "bablas" artinya terus, lewat, kebablasan artinya melebihi batas.

Konsep "persuasi" menurut De Vito (2011:499) usaha melakukan persuasi ini memusatkan perhatian pada upaya mengubah atau memperkuat sikap atau kepercayaan khalayak atauupaya mengajak mereka bertindak dengan cara tertentu. Bahasa persuasif haruslah efektif, hal ini berarti harus menimbulkan efek. Efek menurut Applbaum (dalam Effendy, 2009:80), adalah apa yang terjadi pada persuadee/konsumen sebagai akibat dari dampak stimuli atau pesan dalam bahasa yang digunakan oleh persuader.

Dalam kajian semiotika menurut Ferdinand de Saussure (Fajriannoor, 2013) mengandung 2 unsur, yang diartikan dan yang mengartikan, di dalam kedua unsur ini terdapat unsur intralingual dan unsur ekstralingual. Dalam penelitian ini menitikberatkan pada makna bahasa nonverbal, yang mengacu pada unsur ekstralingual. Seperti yang dilakukan oleh para pedagang melalui tulisannya dalam spanduk dan banner merupakan bagian pembahasan dalam unsur ekstralingual yang dapat memunculkan proporsi makna untuk menentukan makna dan maksud pesan yang disampaikan melalui media tertentu, yakni media luar ruang 
(outdoor) meliputi papan reklame (billboard), spanduk, banner, poster, street furniture, Transit, balon udara, neon box (Kasali, 2007).

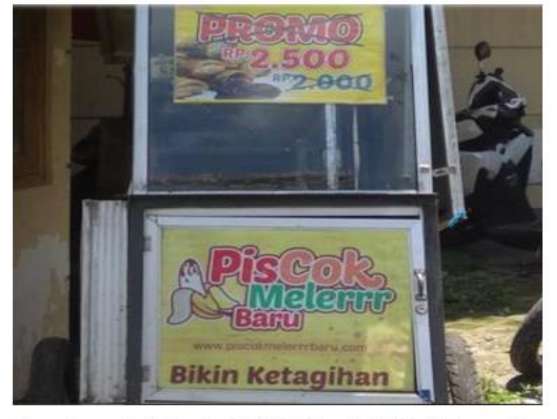

Gambar 3. PisCok Meller Bikin Ketagihan (Sumber: Peneliti, 2020)

Bahasa persuasif: "PisCok Melerrr Baru, Bikin Ketagihan" pada gambar 3, menunjukkan pesan jenis dagangan adalah cemilan atau makanan ringan berbahan pisang yang digoreng dan dilapisi coklat. Jika kita perhatikan variasi warna yang ditampilkan pada tulisan kata-kata persuasif tersebut dan tekanan huruf awal kapital pada frasa "Pis" (kependekan dari kata pisang, yang dituliskan dengan warna merah); frasa "Cok" (kependekan dari kata coklat, namun dituliskan dengan warna oranye) supaya menekankan perbedaan arti kata. Kata "Melerrr" dengan penekanan tambahan akhiran huruf " $r$ " diberi warna hijau yang berasal dari istilah bahasa daerah "meler" berarti mengalir kental, dimaksudkan coklat cair yang mengental melapisi pisang goreng, yang menambah nikmat saat makan pisang goreng.

Berdasarkan beragam temuan di masyarakat dan beberapa dokumentasi media promosi maupun gaya bahasa yang digunakan para PKL dalam pemasaran produk mengandung unsur persuasif, sehingga peneliti tertarik untuk meneliti lebih lanjut tentang model media outdoor ads dalam era milenial ini masih unggul digunakan para pelaku usaha kecil (PKL) di Bali, khususnya di wilayah Denpasar. Adapun permasalahan dalam penelitian ini akan merumuskan:

a) Apa saja gaya bahasa persuasif yang digunakan para pedagang kali lima (PKL) di kawasan Denpasar Selatan?

b) Bagaimana makna atau pesan yang ingin disampaikan oleh PKL tersebut (ditinjau dari padan ekstra lingual)?

Mengingat beberapa hal yang menjadi latar belakang dalam rencana penelitian ini, diperlukan konsistensi dalam menggagas tujuan sebuah penelitian terutama dalam mengkaji penggunaan strategi persuasif dengan media outdoor oleh para PKL di kawasan Denpasar Selatan. Dengan demikian tujuan dari penelitian ini adalah untuk mengetahui:

a) jenis-jenis gaya bahasa persuasif yang digunakan para pelaku usaha pedagang kali lima (PKL) di kawasan Denpasar Selatan.

b) makna ungkapan bahasa atau pesan yang ingin disampaikan oleh PKL tersebut (ditinjau dari padan ekstra lingual).

Berdasarkan latar belakang di atas, manfaat dari penelitian ini, antara lain:

a) Secara teoritis, hasil temuan penelitian ini diharapkan dapat memberikan kontribusi keilmuan dalam bidang bahasa terkait peran ekstralingual dan manfaatnya dalam bidang humaniora khususnya bagi masyarakat pelaku usaha melalui pesan persuasif dan makna informatif bahasa sebagai penanda komunikasi yang bermanfaat bagi konsumen.

b) Secara praktis, penelitian ini diharapkan dapat memberikan kontribusi membuka wawasan semua lapisan masyarakat terutama dalam memperlakukan bahasa promotif/publikatif dengan media cetak berupa spanduk/banner sebagai alat/media promosi yang mempunyai mobilitas tinggi, artinya media spanduk ini dapat dibawa atau dipindahkan sesuai dengan tempat yang diinginkan (Kamus Pusat Bahasa, 2008, h.1372).

c) Diharapkan masyarakat menjadi lebih paham dan selalu optimis bahwa media outdoor ads walaupun terkesan statis namun tetap mampu bersaing bahkan menjadi main ads 
media jika digunakan bersama dengan media yang lebih modern yang justru hanya sebagai media tambahan (additional support media).

\subsection{Penelitian Terdahulu}

Beberapa penelitian terdahulu yang terkait dengan strategi promosi atau pemasaran produk dengan bahasa persuasif, diawali oleh Applbaum (Effendy, 2009) menekankan efektifitas strategi persuasif dalam media iklan harus menimbulkan dampak stimuli atau pesan dalam bahasa yang digunakan persuader terhadap opini dan tingkah laku yang diambil dari kesadaran konsumen terhadap produk yang dipromosikan. (Hartono, 2012) lebih fokus pada riset pasar, memperhatikan kebutuhan konsumen, melakukan promosi, dan memberikan pelayanan yang baik. Penelitian selanjutnya tentang peran strategi komunikasi persuasif (Syamsurizal, 2016) bahwa dalam memasarkan produknya dalam bidang pendidikan (terkait program-program di politeknik LP3I Jakarta) oleh staf pemasaran kepada masyarakat dalam perekrutan mahasiswa baru dengan tujuan untuk meyakinkan calon mahasiswa baru yang mendaftar di Politeknik LP3I. Penelitian Putri (2016) lebih menitikberatkan pada cara memilih dan merancang pesan persuasif melalui bauran komunikasi pemasaran seperti advertising, personal selling, direct marketing, atau public relation yang tepat. Putri lebih lebih menekankan pada teknik penyampaian persuasif melalui komunikasi face to face (media fisik).

\section{Metodologi}

Penelitian ini menggunakan metode deskriptif kualitatif, dengan memaparkan hasil temuan di lapangan menjadi sebuah deskripsi, diawali dengan kegiatan survei di lapangan (field research). Data bersumber dari pedagang kaki lima di kawasan Denpasar Selatan. Obyek penelitian adalah bahasa persuasif yang ditulis/cetak pada spanduk/banner sebagai media promosi para pedagang kaki lima. Pengirim pesan merupakan para pedagang kaki lima/penjual sebagai pihak pemasar, dan penerima pesan adalah calon konsumen yang ingin membeli produknya. Teknik penyajian data dilakukan dengan metode simak dan catat. Sedangkan teknik pengumpulan data dengan dokumentasi dan pendistribusian kuesioner.

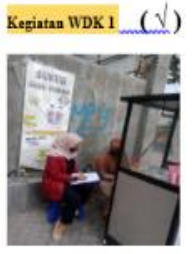
Kegiatan WDK $2(\sqrt{ })$
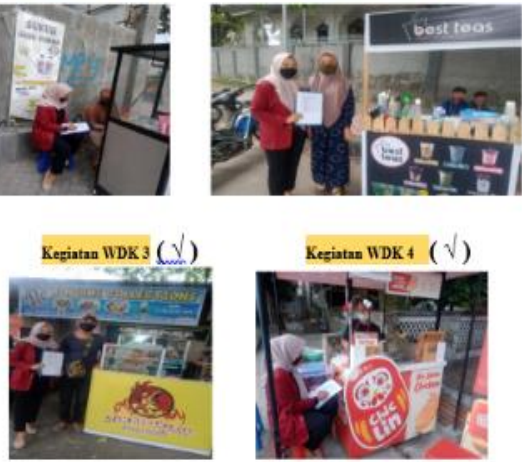

Gambar4. Dokumentasi kegiatan Pengumpulan data (Sumber :peneliti, 2020)

Metode pelaksanaan di lapangan dengan survei dan kunjungan ke emperan toko dan pinggiran jalan. Kemudian dikonsultasikan dengan reviewer Bahasa. Selanjutnya dilakukan pengecekan kembali kelengkapan data di lapangan untuk diolah dan disesuaikan berdasarkan klasifikasi hasil review dari advisor Bahasa, khususnya unsur lingual terhadap data yang telah dikelompokkan dengan menitikberatkan pada gaya bahasa persuasif berupa kata-kata, frase atau model tulisan "nyeleneh" atau antimainstream dan daya tarik visual latar belakang tulisan (background support) pada banner, dalam bentuk list dengan populasi 50 dan sampel 30 bahasa persuasif pada banner PKL seperti pada tabel 1 berikut. 
Tabel 1. Data Kajian Unsur Lingual \& Media Ads

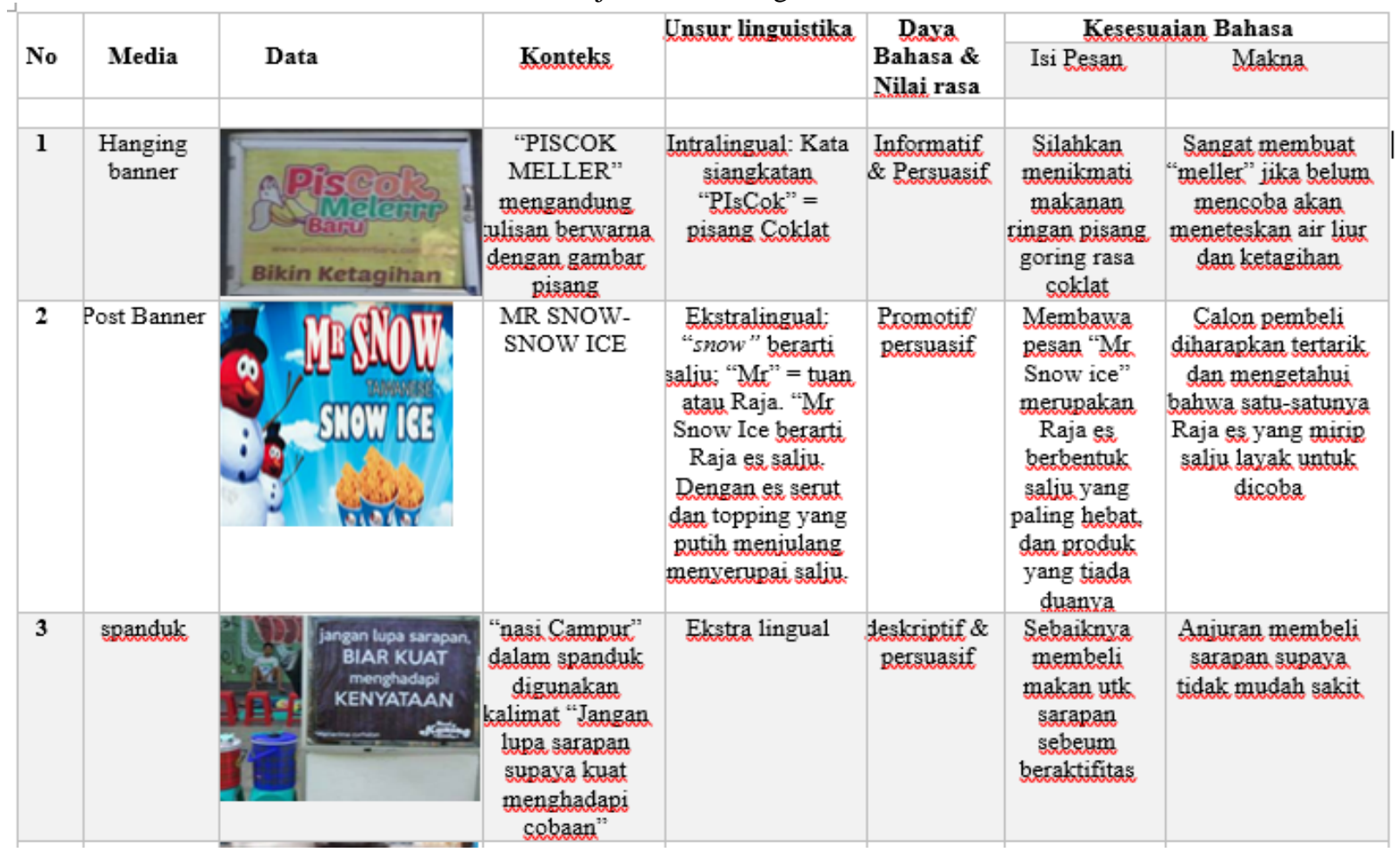

(sumber: peneliti, 2020)

Teknik analisa, dilakukan penghitungan tingkat akurasi data yang dikaji dan dijelaskan pada dalam tabel (ditunjukkan pada tabel 3 dan 4 dalam hasil analisa) dengan menggunakan analisa frekuensi dan analisa mode pada Skala Likert. Berdasarkan penghitungan rating scale akan ditunjukkan penghitungan dalam tabel untuk menunjukkan jenis interval pada kuesioner responden sesuai penghitungan terhadap variabel pertanyaan (ditunjukkan pada tabel 2).

Tabel 2. Data Interval Kuesioner

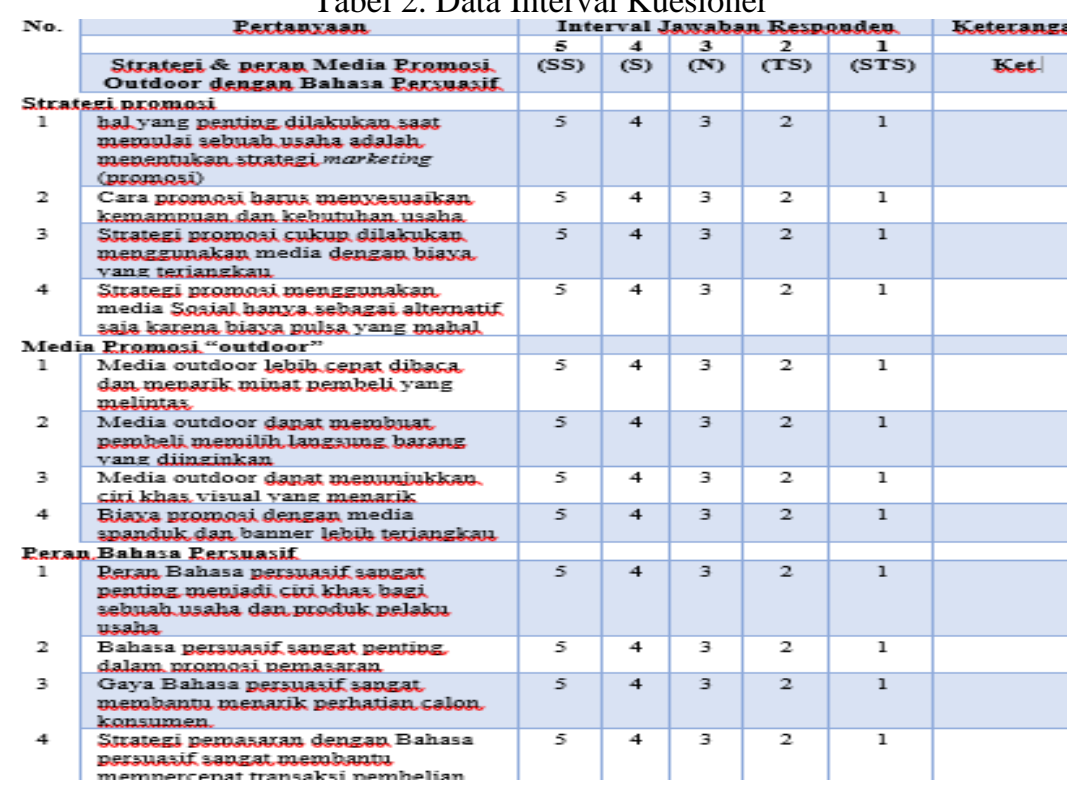

Penghitungan tingkat akurasi berdasarkan instrumen yang disebarkan kepada responden seperti telah ditunjukkan pada tabel 2 di atas, penilaian 5 bila peran sangat setuju; 4 bila peran setuju; 3 bila peran netral; 2 bila peran kurang setuju; 1 bila peran sangat tidak setuju. Hal ini berarti bahwa skor tertinggi tiap butir $(\mathrm{Hi})=5$, jumlah butir $(\mathrm{Tq})=12$, jumlah responden $(\mathrm{Tr})=$ 30. Dengan Rumus: $\boldsymbol{T a}=(\boldsymbol{H i} \boldsymbol{x} \boldsymbol{T} \boldsymbol{X} \boldsymbol{X} \boldsymbol{T}): \boldsymbol{H i}$ menunjukkan start interval terendah dari nol (0) dan closing interval tertinggi (1800) seperti penghitungan pada tabel 5. 


\section{Hasil dan Pembahasan}

\subsection{Hasil Temuan}

Berdasarkan hasil observasi dengan dokumentasi \& pendistribusian kuesioner, ditemukan data yang kemudian di-list berupa bahasa persuasif pada media outdoor ads (spanduk atau banner) para PKL, seperti pada gambar berikut.

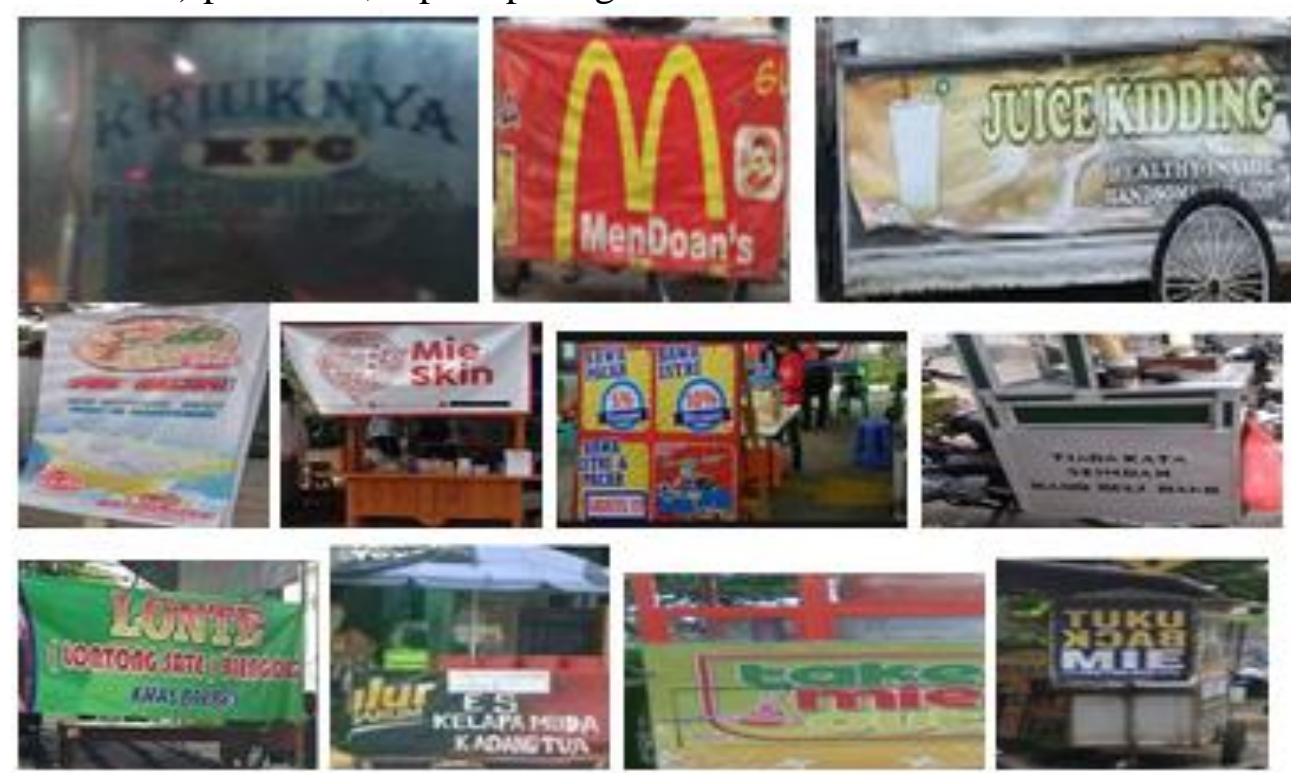

Gambar. 5 Dokumentasi bahasa persuasif pada media outdoor ads PKL (Sumber: peneliti, 2020)

Berdasarkan hasil catatan dan metode simak di lapangan, serta proses WDK yang dilakukan di lapangan, telah ditemukan 4 kategori jenis penggunaan bahasa promotif yang digunakan para pedagang keliling tersebut, antara lain: kata-kata antimainstream $11 \%$, kalimat lucu dan informatif $28 \%$, kalimat instruktif $20 \%$, frasa unik berciri khas produk dan pedagang $41 \%$.

\subsection{Hasil Analisa \& Pembahasan}

Berdasarkan hasil analisa, dilakukan penghitungan tingkat akurasi data yang dikaji dan dijelaskan pada tabel berikut. Adapun AF (analisa frekuensi) dan AM (analisa mode) telah dijelaskan juga dalam tabel 3 berikut.

\begin{tabular}{|c|c|c|c|c|c|c|c|c|c|c|c|c|c|}
\hline No & \multicolumn{5}{|c|}{ Jawaban Kesponden } & \multicolumn{5}{|c|}{ Analisa Freksuensi (Proporsi) } & \multicolumn{2}{|c|}{$\begin{array}{c}\text { Analisa } \\
\text { Gabungan }\end{array}$} & Kersentase \\
\hline ariabel & SS & $\mathbf{S}$ & $\mathbf{N}$ & TS & STS & SS & $\mathrm{S}$ & $\mathrm{N}$ & TS & STS & $\mathrm{KS}(\%)$ & $\mathrm{KTS}(\%)$ & Keterangan \\
\hline 1 & 7 & 11 & 8 & 4 & 0 & 23.31 & 36.63 & 26.64 & 13.32 & 0 & 59.64 & 13.32 & 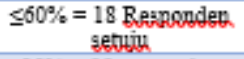 \\
\hline 2 & 20 & 8 & 0 & 1 & 1 & 66.6 & 26.64 & 0 & 3.33 & 3.33 & 93.24 & 6.66 & $\begin{array}{c}95 \%=28 \text { reapouden } \\
\text { sevuju }\end{array}$ \\
\hline 3 & 9 & 15 & 0 & 3 & 3 & 29.97 & 49.95 & 0 & 9.99 & 9.99 & 79.92 & 19.98 & $\begin{array}{c}\leq 80 \%=24 \text { Berponden } \\
\text { Setuju }\end{array}$ \\
\hline 4 & 12 & 9 & 2 & 4 & 3 & 39.96 & 29.97 & 6.66 & 13.32 & 9.99 & 69.93 & 23.31 & $\begin{array}{c}\leq 70 \%=21 \text { Berponden } \\
\text { Setuiu }\end{array}$ \\
\hline 5 & 25 & 2 & 0 & 3 & 0 & 83.25 & 6.66 & 0 & 9.99 & 0 & 89.91 & 9.99 & $\begin{aligned} 90 \%= & 27 \text { Bespapdea } \\
& \text { senuin }\end{aligned}$ \\
\hline 6 & 16 & 9 & 4 & 1 & 0 & 53.28 & 29.97 & 13.32 & 3.33 & 0 & 83.25 & 3.33 & $\begin{array}{c}83.25 \%=24 \\
\text { Berponden setuiy }\end{array}$ \\
\hline 7 & 10 & 20 & 0 & 0 & 0 & 33.3 & 66.6 & 0 & 0 & 0 & 99.9 & 0 & $\begin{array}{c}100 \%=30 \text { Resprnden } \\
\text { Setujus }\end{array}$ \\
\hline 8 & 15 & 15 & 0 & 1 & 1 & 49.95 & 49.95 & 0 & 3.33 & 3.33 & 99.9 & 6.66 & $\begin{array}{c}100 \%=30 \text { Reapsonden } \\
\text { Setuis }\end{array}$ \\
\hline 9 & $I 2$ & 15 & 3 & 0 & 0 & 39.96 & 49.95 & 9.99 & 0 & 0 & 89.91 & 0 & $\leq 90 \%=\underset{\text { Setuius }}{27 \text { Reaponden }}$ \\
\hline 10 & 12 & 18 & 0 & 0 & 0 & 39.96 & 59.94 & 0 & 0 & 0 & 99.9 & 0 & $\begin{array}{c}100 \%=30 \text { Resprnden } \\
\text { Setuiu }\end{array}$ \\
\hline 11 & 25 & 2 & 0 & 3 & 0 & 83.25 & 6.66 & 0 & 9.99 & 0 & 89.91 & 9.99 & $\begin{array}{c}83.25 \%=27 \\
\text { Respanden Setuin }\end{array}$ \\
\hline 12 & 25 & 2 & 0 & 3 & 0 & 83.25 & 6.66 & 0 & 9.99 & 0 & 89.91 & 9.99 & $\begin{array}{c}83.25 \%=27 \\
\text { Respapden Setrip }\end{array}$ \\
\hline
\end{tabular}

(sumber: peneliti, 2020) 
Tabel 4. Hasil AF Tertinggi Terhadap AM (Skala Linkert)

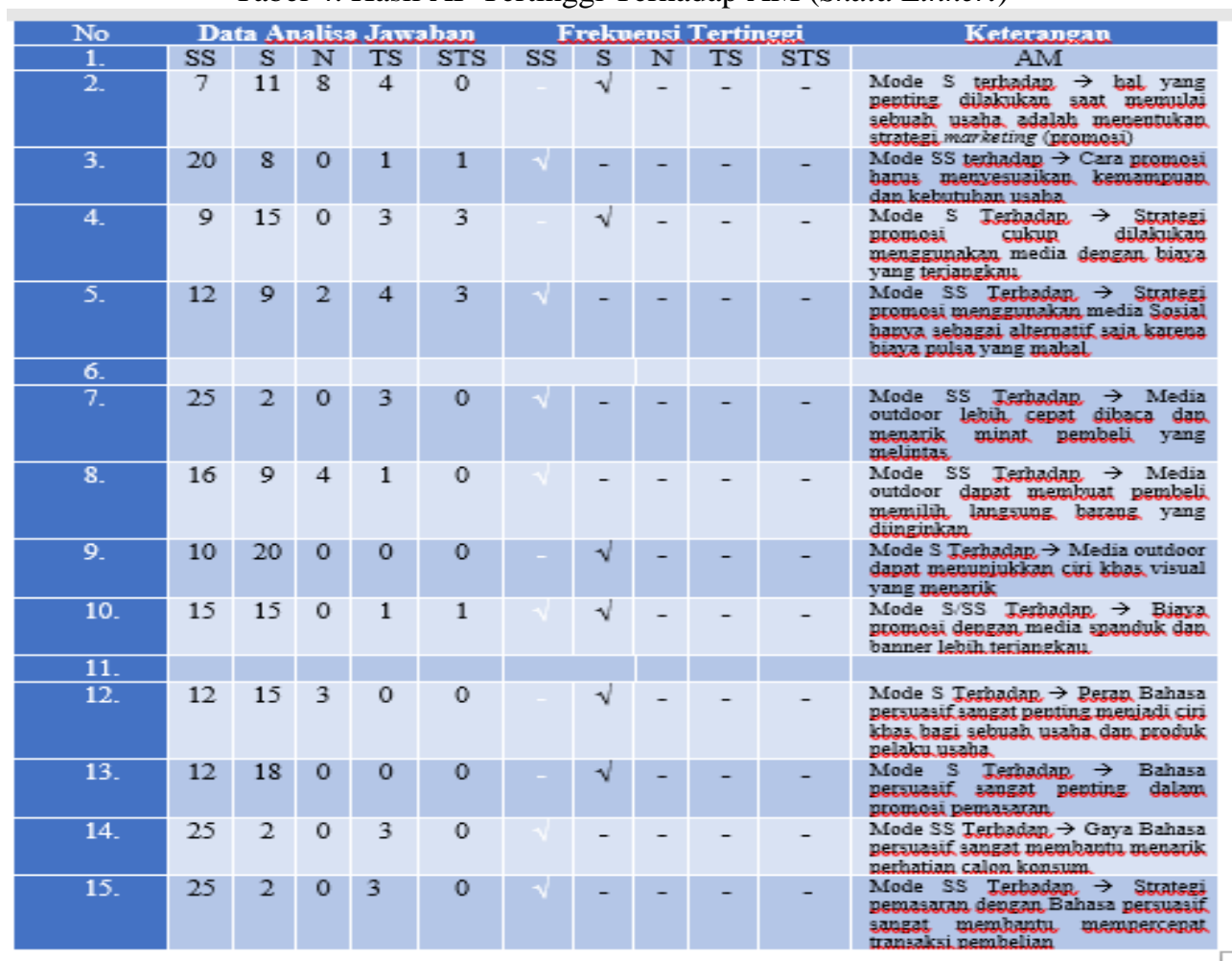

(sumber: peneliti, 2020)

Berdasarkan penghitungan rating scale menunjukkan jenis interval pada kuesioner responden sebanyak 12 variabel, telah dilakukan penghitungan tingkat akurasi berdasarkan instrumen yang disebarkan kepada responden seperti ditunjukkan pada tabel 5 di bawah. Penilaian 5 bila peran sangat setuju; 4 bila peran setuju; 3 bila peran netral; 2 bila peran kurang setuju; 1 bila peran sangat tidak setuju. Hal ini berarti bahwa skor tertinggi tiap butir $(\mathrm{Hi})=5$, jumlah butir $(\mathrm{Tq})=12$, jumlah responden $(\mathrm{Tr})=30$ dengan dirumuskan berikut.

$$
\Rightarrow \text { Rumus : }
$$

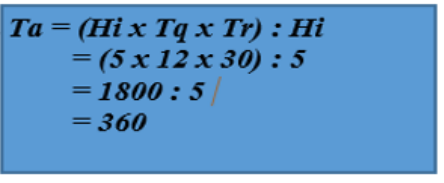

$\Rightarrow$ Start interval terendah dari 0 adalah 360

$\Rightarrow$ Closing interval tertinggi adalah 1800 .

Tabel 5. Jawaban Responden Terhadap Variabel pertanyaan

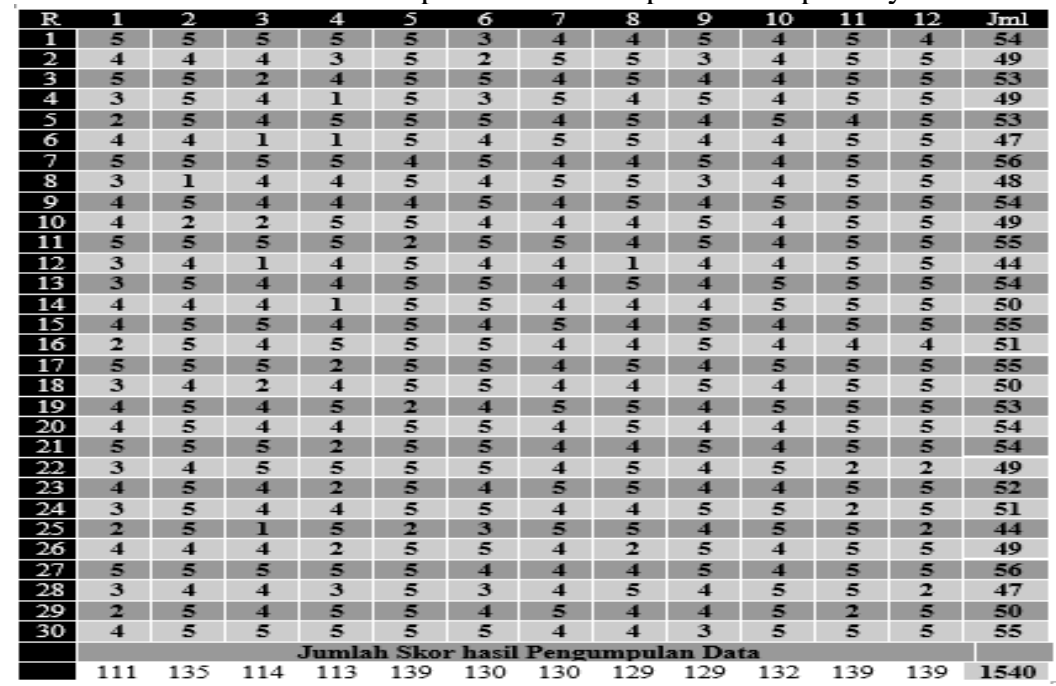


(sumber: peneliti, 2020)

Jumlah atau total penghitungan yang ditunjukkan pada tabel $5=1540$ menunjukkan kategori 1540 sama dengan sekitar $80 \%$ penggunaan media banner/spanduk dengan Bahasa persuasif sangat sesuai dengan kebutuhan strategi promosi PKL di wilayah Denpasar Selatan. Penyampaian makna pesan kepada publik (calon konsumen) sebagai strategi promosi produk merupakan pilihan yang tepat saat ini.

\section{Kesimpulan}

Pada kategori interval menunjukkan bahwa jumlah skor hasil pengumpulan data angket kepada responden 1540. Dengan demikian kategori interval 1540 berada antara S (Setuju) dan SS (Sangat Setuju), mendekati interval S "setuju" seperti digambarkan pada chart 1 berikut. Kategori 1540 pada interval "S" menunjukkan bahwa sekitar 80\% penggunaan media banner/spanduk dengan bahasa persuasif sangat sesuai dengan kebutuhan strategi promosi PKL dalam menyampaikan pesan kepada khalayak (calon komsumen) sebagai strategi promosi produk, yang dapat memudahkan calon pembeli dalam memilih langsung produk yang diinginkan, sehingga pembeli merasa puas dan makin berminat membeli, secara otomatis meningkatkan omset penjualan dan pendapatan PKL lebih baik.

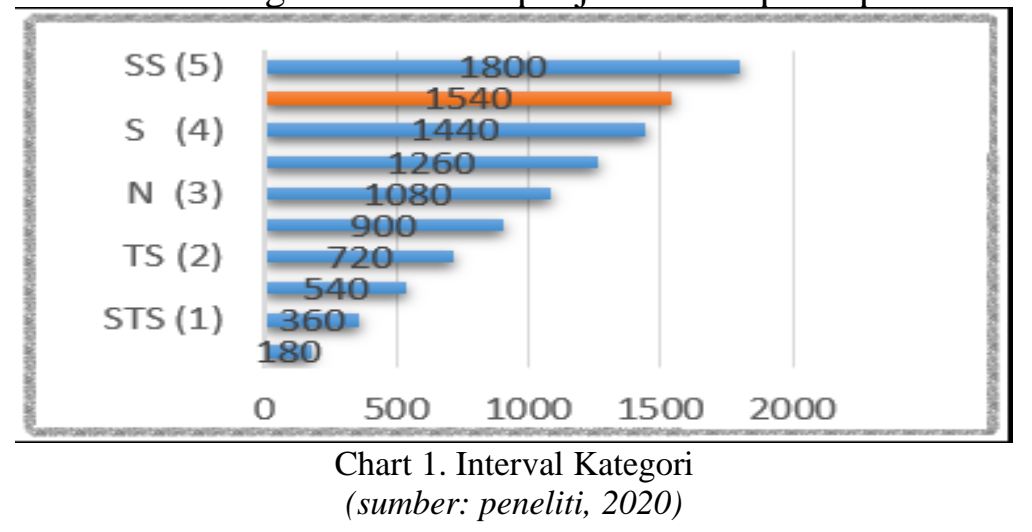

\section{Saran}

Pada penelitian selanjutnya diharapkan:

a) Penelitian ini mampu menjadikan dasar pemikiran dalam mengembangkan gagasan dan kesadaran berkreasi bagi para pelaku usaha atau PKL dalam mempromosikan produk melalui media outdoor yang lebih variatif dengan biaya yang sama terjangkau.

b) Hasil penelitian ini mampu menginspirasi para pelaku usaha di kawasan lain untuk bisa meningkatkan karya dalam strategi mempromosikan produknya, dengan tetap menggunakan bantuan media tekhnologi minimal melalui smartphone supaya bisa mengikuti perkembangan dalam mengetahui daya saing di dunia usaha.

c) Penelitian selanjutnya mampu membantu para PKL dalam memberikan pendampingan terkait peluang marketplace ataupun sejenisnya untuk menambah wawasan para PKL dalam pemanfaatan media teknologi, sehingga mampu melengkapi strategi pemasaran PKL saat ini.

\section{Ucapan Terimakasih}

Penelitian ini didanai oleh LPPM STMIK STIKOM Indonesia Tahun Anggaran 2020 dengan nomor surat Perjanjian penugasan: 73/04/LPPM/PDM/VI/2020.Terimakasih kami sampaikan kepada LPPM STMIK STIKOM Indonesia. Kami juga mengucapkan terimakasih kepada Ketua STMIK STIKOM Indonesia, Ka Prodi Teknik Informatika dan Sistem Informasi, Ka. LPIK dan Ka. Lab. komputer atas dukungan fasilitas yang dapat menunjang kelancaran penelitian ini. Terimakasih juga kepada para reviewer sekaligus sebagai advisor dalam mengarahkan data kajian bahasa persuasif dan makna pesan unsur lingual pada penelitian ini, juga kepada kedua tim anggota peneliti yang sangat membantu dan mendukung proses WDK di lapangan, dan para PKL di wilayah Denpasar. Kami sebagai tim penulis juga 
mengucapkan terimakasih kepada segenap dewan redaksi jurnal JSHP, tim editor dan reviewer artikel kami, sehingga karya ini bisa ter-publish dan insyaalah dapat menjadi referensi yang bermanfaat bagi masyarakat.

\section{Daftar Pustaka}

Anonim. 2008. Kamus Bahasa Indonesia, (Jakarta: Pustaka Pelajar, 2008), hlm. 210.

Asmaunizar., dkk. 2020. Bisnis Iklan Media Cetak Dalam Mensejahterakan Karyawan. http://jurnal.ar-raniry.ac.id/index.php/peurawi. Jurnal Peurawi EISSN: 2598-6031 ISSN: 2598-6023. Vol. III No. 1 Tahun 2020. DOI: 10.22373/jp

Boyd, Harper W. 2000. Manajemen Pemasaran: "suatu pendekatan strategisdengan orientasi global", Jakarta: Erlangga.

Carita, Yohanna E., dkk. 2016. Kajian Visual Poster Profauna Indonesia Seri "Mencintai Mestinya Tidak Dikurung". Jurnal: Dimensi DKV, Vol.1-No.2 Oktober 2016; h.2.ISSN : 25027425 e-ISSN : 25497766 DOI : -jurnaldimensidkv@ trisakti.ac.id.

De Vito, Joseph A. 2011. Komunikasi Antarmanusia, Edisi Kelima. Jakarta: Karisma Publishing Group.

Effendi, Onong Uchjana. 2009. Ilmu Komunikasi: Teori dan Praktek. Bandung: PT Remaja Rosdakarya

Fajriannoor, Fanani. 2013. Semiotika Strukturalisme Saussure. Jurnal THE MESSENGER, Volume V, Nomor 1, Edisi Januari 2013.http://journals.usm.ac.id/index.php/themessenger/article/viewFile/142.https://doaj.org/toc/2527-2810.

Gitosudarmo. 2000. Manajemen Pemasaran. Cet ke-6. Yogyakarta: BPFE.

Handoko, Bagyo. 2010. Pedagang Kaki Lima (PKL) sebagai Bibit Entrepreneur Dalam Mengatasi Pengangguran. Jurnal: Econosains, vol. III no.2, Agustus 2010.

Hartono, Hendry. et. al. 2012. "Pengaruh Strategi Pemasaran Terhadap Peningkatan Penjualan Pada Perusahaan Dagang Menetapkan Alumni Dan Mahasiwa Universitas Bima Nusantara Sebagai Objek Penelitian”, Binus Business Review. Vol. 3 No. 2, November 2012.

Kasali, Rhenald. 2007. Manajemen Periklanan Konsep dan Aplikasinya di Indonesia. Jakarta: Pustaka Utama Grafiti.

Putri, Primadhany K. 2016. Aplikasi Pendekatan-Pendekatan Persuasif Pada Riset Komunikasi Pemasaran: Iklan Melibatkan Penciptaan dan Penerimaan Pesan Komunikasi Persuasif Mengubah Perilaku Pembelian. Jurnal THE MESSENGER, Volume VIII, Nomor 1, Edisi Januari 2016.Journals.usm.ac.id/index.php/themessenger.https://doaj.org/toc/2527-2810.

Swastha, Basu. 2007. Pengantar Bisnis Modern, Edisi ketiga, Cet ke-11, h.222. Yogyakarta:Liberty Yogyakarta. 